\title{
Bridging Academic Entrepreneurship and the World of Work? Perspectives from Contemporary Educator
}

\section{TECK CHOON TEO}

American University of Phnom Penh, Cambodia.

\begin{abstract}
This contribution of this study investigates how the use of the AE toolkit can take the lead to a greater appreciation of the university spin-off venture into the real world of work. Nevertheless, no conceptual framework can explain how the technology-market matching proceeds from one stage to another. Alongitudinal survey design involving four focus groups was chosen to monitor the development process of group spin-off creation in context. Data collection is also derived from the literature review, in-depth interviews, and a series of workshops and focus group discussions on the Malaysian and Cambodian higher education sectors. Finding shows that the AE toolkit is organized around four mutually dependent themes: (1) the structure of an enterprising university and its culture, (2) university spin-offs (USOs) and applied research, (3) the attribute of academic entrepreneurs and entrepreneurial ecosystem, and (4) spin-off development and community engagements. These theories may offer a more comprehensive insight into the $\mathrm{AE}$ process in conjunction with each other. The beliefs of each notion hint at significant consequences for further research on $\mathrm{AE}$ and the world of work as a general rule.
\end{abstract}

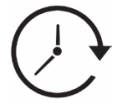

Article History

Received: 06 May 2021

Accepted: 17 June 2021

\section{Keywords}

Academic

Entrepreneurship;

Development;

Spin-Offs;

Start-Ups;

Technology Transfer

Office (TTO);

University Technology-

Market Matching.

\section{Introduction}

The genesis of academic entrepreneurship (AE) has to be viewed from the perspective of the environment and the objective of universities, which can have an enduring custom. Traditionally, universities are considered learning institutions as repositories and generators of knowledge-the commitment to prepare graduates to find viable employment. For profitable entrepreneurship, benefit or worth is more often than not dictated by the innovation of novelty products or services that consumers are prepared to buy and turn a profit for the entrepreneur. However, corroboration emphasizes the university's third mission, which has not seen a deterioration in fundamental research (Siegel and Wright, 2015a). Van Nguyen et al (2018) also echo that an emphasis on commercialization and academic entrepreneurship actually supports basic

CONTACT Teck Choon TEO ${ }_{\text {t.teo@aupp.edu.kh }}$ American University of Phnom Penh, Cambodia.

\section{(c) (i)}

(C) 2021 The Author(s). Published by Enviro Research Publishers.

This is an Open Access article licensed under a Creative Commons license: Attribution 4.0 International (CC-BY).

Doi: http://dx.doi.org/10.12944/JBSFM.02.01.12 
research, and primarily the profits are plowed back. To put into context, technology-market matching refers to the process of implementing research results to practices, whereas technology-market matching relating to financial exchanges is defined as commercialization (Nguyen et al., 2018).

$A E$ is not a new phenomenon and is frequently used to develop economic activity. The extant literature of $A E$ underscores the many barriers limiting and often inhibiting the scientific community's economic activity, such as the lack of academic and explicit provisions, restricted access to financial resources, and competent executives (De Boer \& Enders, 2017). Not to mention all the risk associated with the market's specificity for intellectual property, impediments of invention's anticipated worth, and the clarity of IP (intellectual property) rights adds to the woes of the academic entrepreneurs. Specific literature has also compared the wisdom of university teaching to the world of work (Scott \& Kirst, 2017).

With the acute interest in academic entrepreneurship nowadays, university spinoffs and entrepreneurial academics are likely potential sources of current elevated disruptive innovations. AE contributes economically to the success and growth of regions and countries (Marzocchi et al., 2019). Hence, understanding both the process and likely impacts of AE subsumed as commercialization positively affects economic growth (Balven et al., 2018).

Several factors characterize the development of $A E$. This relates mainly to the difficulties of the entrepreneurial environment. On the whole, an environment is created by political, economic, social, technological advancement impacts entrepreneurship. The primary support for the success of AE stems from the favorable grants from relevant commercial organizations and the university-based venture funds, for example, an academic business incubator to support innovation and entrepreneurship of faculty and postdocs.

But, increasingly, professors need not surrender academic liberty in exchange for commercializing scientific findings. Nowadays, there is such a provision for a third career path of what is known as $A E$. However, as in all situations, there are barriers to AE: Namely, academic entrepreneurs must have unique knowledge and applicable skillsets such as recognizing opportunities for business and creating customer value, and the disposition of risk-takings. Given the right set of professors' attitudes and skills, university culture can yet be another formidable disincentive. Conventional science education is not supportive of entrepreneurship, thus deterring fresh scientists. School managers frequently hold the opinion that Ph.D. students and postdocs should focus exclusively on research. An additional impediment is that too many patents and start-up companies may count for little during hiring and promotion.

Since there is no systematic, academic toolkit to teach people in entrepreneurship, this study is intended to give a comprehensive view of the $A E$ process by using the $A E$ toolkit, which is built on four mutually dependent themes. In this regard, these mutually dependent thematic concepts can facilitate the university spin-off venture into the real world of work. Evoking all four thematic ideas together will shed light on different aspects of the AE phenomenon. This paper contemplates a new approach to $A E$ delivery by presenting a toolkit centered on industry and technology connectivity, experiential learning, and reflective practice.

This study is intended to understand the university spin-off trend better but does so at the expense of simplicity of justification. The results indicate that different processes are more relevant at specific times in the spin-off process and that each development inherently focuses on other aspects of the process. As a consequence, many research issues in entrepreneurship would benefit from using a combination of thematic concepts. This qualitative, conceptual paper will first discuss relevant literature on university spin-off processes and defines the conceptual boundaries to guide studies related to venture-building activities. Within this approach, the data from a longitudinal survey of four focus group spin-off processes are introduced. The findings are discussed with the real world of work, and the university spin-off process is advocated. Finally, suggestions for potential theoretical exploration of the AE process will conclude this conceptual paper with due regard of the limitations and practical and theoretical implications of the framework as well as making recommendations for future research. 


\section{Relevant Literature}

In exploring the various notions and definition of academic entrepreneurship, the extant literature indicates at least three standards widely accepted taxonomies:

\section{Commerce Definition}

According to Gubbins et al. (2020) posits that the fundamental definition of academic entrepreneurship has the genesis from commercial profitability and the development of university spin-offs (USOs). (Van Toan, 2021; Audretsch, 2014). While other writers had taken into account any business created based on intellectual property generated within the universities, regardless of the entrepreneur was a member of the academia or not (De Almeida Borges et al., 2020). It is interesting to note that the definitions only refer to entrepreneurial goals without monetary value through knowledge transfer. The following two categories of definitions expanded the scope and challenged the perception.Ziyae \& Tajpour (2016) asserts that there is a positive and significant effect of the organizational, individual, institutional, and environmental factors on entrepreneurial university in the science and technology parks.

\section{Transfer Knowledge Definitions}

The juxtaposition of technical skills and capabilities of universities is frequently neglected (Dost et al., 2019; Rao, 2019). Tajpour et al., (2017) defended the notion of positive effect of the suggestion scheme on the creativity of the staff in the banking sector. Although writers like Melkas et al. (2019), Pisoni et al. (2018), Steinfield \& Holt (2019) consider $A E$ as the means of enterprise development through revolutionizing academic knowledge, which effectively is the basis of monetary value creation. Pilegaard et al. (2010) contend that academe and business cooperation and partnership are prevalent. Mohar et al. (2010) went even further to advance AE as the central tenet for corporate turnaround and business sustainability.

\section{Value-add Definitions}

The final category of definition holds the view of entrepreneurship as a cradle of societal value, however not placing the importance on monetary value and demonstrating value and credibility of researchers and professors. The relationship between industry and academe are inseparable and remain profound and multi-faceted, with their futures intertwined. Looking ahead, both must forge a long-term sustainable relationship and gain mutual benefits where the industry makes academic research appropriate and industry resilient and innovative. When evaluating collaboration between companies and universities, it is not simply about assessing traditional hard metrics such as investment dollar and trade volume, but also other qualitative measures. There are at least two areas - one is in the way is developing human capital (talent), the other on harnessing technology together to make local companies more competitive.

Corresponding to Hogan et al. (2021) allude that business schools and faculties play a constructive role in universities' mission through $A E$. Yet $A E$ is an intrinsically abstract concept. Recent findings describe $A E$ as an integral part of the university's technology-market matching and the advent of the USO (Wadhwani et al., 2017). Phan \& Siegel (2006) credits the $A E$ with the endeavors undertaken by schools to encourage entrepreneurship pursuits. This point resonates with Hayter et al. (2018) research, which shows that USOs are a crucial means for economic and social development. Universities must face new challenges to meet expectations for entrepreneurial growth. Thirdgeneration universities are generally entrepreneurial and based on entrepreneurship and solving social problems with a scientific approach (Tajpour et al., 2020).

A richness of literature has been written on one such area, namely academia (Zhylinska et al., 2019; Tajpour \& Hosseini, 2019; Siegel and Wright 2015a, 2015b). This literature's primary focus on $A E$ is on technology-market matchingactivities in universities. It incessantlyfeigns that $A E$ is a relatively new development. Contrastingly, Łukasz (2015) defines AE as entrepreneurial activity in education and its practical help for people associated with the research. Other terms are also used for the firmsset up by universities, such as USO and small technology business forms (Banerski et al., 2009, p. 6). Mars and Rios-Aguilar (2010) highlight that AE's endeavors primarily discriminate entrepreneurial frameworks to market-oriented phenomena in the higher education sector. Furthermore, De Silva (2016) categorized entrepreneurial commitment of academics as teaching or research-related academic entrepreneurial behaviors. 
There is mounting critique targeted at professors' activities, mainly in the indictment of faculties and staff that they are overly fixated on technical domains with little or no valuable applications (Jack 2020). Fleming (2020) highlights the urgency of transforming academic and theoretical skills to a pragmatic, real-world context from a different perspective.

Not with standing the overwhelming interest in $A E$ in academic trends, it is imperative for the USOs and academic entrepreneurs to leverage R \& D outcomes for commercialization (Wright et al., 2008). Arguably, it involves professors and researchers serving as boards of advisors in universities from a specific support standpoint. They can provide the critical impetus that the management panel may otherwise lack (Wright et al., 2008). Hence, the responsibility of business connections may prove to be an essential component of the AE process. Again, this should not explain the rationale without knowing the chronology where business connections are needed. Table 1 offers alternate views about the process of spin-off enterprises by contrasting USO firm creation with the divergence and system approaches (Mohr, 1982; Van de Ven \& Poole, 2005). As exemplified, the fundamental beliefs of the system approach seem to be more suitable for taking the anomalies and variety of spin-off processes (Mustar et al., 2006) by comparison with the divergence approach.

Table 1: Views about USOs, Divergence and System Approaches

\begin{tabular}{lll}
\hline Views about USO firm creation & Divergence Approach & System Approach \\
\hline $\begin{array}{l}\text { Concept of spin-off and participating } \\
\text { actors in the process can vary over time }\end{array}$ & $\begin{array}{l}\text { Firms with diverging } \\
\text { characteristics }\end{array}$ & $\begin{array}{l}\text { Firms take part in trials } \\
\text { and can vary over time }\end{array}$ \\
$\begin{array}{lll}\text { Disruptive incidents and circum- } \\
\text { stances may alter spin-off processes }\end{array}$ & $\begin{array}{l}\text { Justifications based on essential } \\
\text { and appropriate connection }\end{array}$ & $\begin{array}{l}\text { Justifications based on } \\
\text { essential connection }\end{array}$ \\
$\begin{array}{l}\text { USOs are contextualized and no two } \\
\text { spin-offs processes are similar }\end{array}$ & $\begin{array}{l}\text { Simplification hinges on standar } \\
\text {-dization across context }\end{array}$ & $\begin{array}{l}\text { Simplification hinges } \\
\text { adaptability across cases }\end{array}$ \\
$\begin{array}{l}\text { Curating is critical part of spin-off } \\
\text { processes }\end{array}$ & $\begin{array}{l}\text { Time arrangement among } \\
\text { independent variables are } \\
\text { inconsequential }\end{array}$ & $\begin{array}{l}\text { Time arrangement of } \\
\text { independent events are vital }\end{array}$ \\
$\begin{array}{l}\text { Past experience and track record of } \\
\text { participating actors can shape } \\
\text { the spin-off process }\end{array}$ & Importance on direct connection & $\begin{array}{l}\text { Explanations are considered } \\
\text { and integrated both }\end{array}$ \\
$\begin{array}{l}\text { immediate and peripheral } \\
\text { influence the spin-off process }\end{array}$ & $\begin{array}{l}\text { Traits have a specific } \\
\text { meaning over time }\end{array}$ & connection \\
\hline
\end{tabular}

Source: Modified from Mohr (1982) and Van de Ven and Poole (2005)

Research Questions and Defining Conceptual Boundaries

The study is mainly instructive and exploratory. It informs university managers towards constructing the pragmatic and helpful framework that can facilitate the technology-market matching leading to radical, innovative products or services, thereby generating opportunities in the corporate spheres.
Further, it seeks to examine the causal tie-in between $\mathrm{AE}$ and start-up companies. The extant literature reviewed yielded three critical research questions $(\mathrm{RQ})$

- Exactly how the cultivation of business enterprise invigorates academic entrepreneurship? 
- What university/institution considerations possibly impede the university's third mission and enterprise incubation?

- How can universities/institutions promote the university's third mission amongst academics and a herald successful business enterprise incubation?

In framing the commercialization pursuits, firstly, the output for academic entrepreneurs will invariably require academics to patent, license intellectual property, and create spin-off companies usually developed through business enterprise incubation. Secondly, encouraging academics to pursue commercialization activities will require collective institutional support if academic entrepreneurship is part and parcel of a university's strategic direction.

\section{Defining the Conceptual Boundaries}

- Zoom in on the responsibility of the faculties and schools in championing technology-market matching.

- Explore the sustainable role of the faculties and schools affecting academic entrepreneurship.

- Understand strategies that influence technologymarket matching.

\section{Methodological Approach and Data Collection Study Environment and Case Selection}

The research was conducted in Malaysia and Cambodia, which can be viewed as normal Asian developing countries involving business activities and the higher education system. The selected higher learning institutions are privately funded and contend with a growing contest for research funding and opportunities for creating peripheral revenue. In recent times private universities and colleges are eager to be engaged in future spin-off ventures by way of generating supplementary income for the institutions. Most of the IP (intellectual property) of university-based research was retained by the faculty members. The formation of TTOs quickly led to the technology-market matching and heightened possibility of USO. This advancement is similar to the evolution which has taken place in many other countries, and the continuing development in collaborating partnership with industry with the intention of commercialization has become more apparent and transparent.
Potential cases were carefully chosen in collaboration with knowledgeable academe at the university. Preferably, all cases need to be at an early stage where technology-market matching is absent, and there is no funding feasibility yet. To facilitate the description of USO, the chosen cases have the university as the mother organization, and the professors and research staff are pivotal in the launch of AE development. Approval to gather data was agreed upon between parties safeguarding a rich supply of data, and two cases within each university were chosen as part of the study.

\section{Data Collection}

A longitudinal survey design involving four focus groups was chosen to monitor the development process of group spin-off creation in context. Data collection is also derived from the literature review, in-depth interviews, and a series of workshops and focus group discussions on the Malaysian and Cambodian higher education sectors. The extant literature provided a broad overview of the development of the commercial industries and innovation policies. Through the assessment, key actors in academia, industry, and policymakers were identified.

A total of 20 professionals were interviewed. All interviews were documented with participants' permission, entirely transcribed by two research assistants, and analyzed by the author. The profiles of interviewees are not presented in further detail to respect individuals' privacy.

Most interviewees were engaged in either research and development in universities and were senior researchers in their respective fields for several years. The interview questions were structured using the inventory of activities under scoring the principal tasks in developing the specific technology that the interviewee has been working on and the particular actions the interviewee undertook to address these challenges. The interview scripts addressed:

- The extent of value add in USO and technologymarket matching activities;

- How competition may create an opportunity as well as a threat to the development of USO;

- Why ambiguous policies present new prospects for TTOfor fostering the world of work; 
The data collectedfrom the interviews were encoded and analyzed with the crucialdiagnosticgenres from the literature review. The encoded and triangulated data analysis included searching for general outcomes among interviews (Yin, 2003), thus reinforcing the research's authenticity.

The spin-offs ventures and the parent organization are based on detailed structured interviews with actors from the university and the firms. The respondents were identified as key individuals in the collaboration between the parent research organization and the firms. They typically held the Chief Technology Officer (CTO) position at the spinoff organization and researcher (or professor) at the parent research organization. With the following consent by the respondents, interview reports were analyzed with RQDA (qualitative analysis software), which assisted in the categorization of the text fragments corresponding with the various elements of the qualitative interviews (see Table 2).

Table 2: Codingapplied in Qualitative Analysis of the Interviews

\begin{tabular}{|c|c|c|}
\hline & Coding category & $\begin{array}{l}\text { Number of interview } \\
\text { fragments }\end{array}$ \\
\hline \multirow[t]{6}{*}{ Mechanisms } & 02a Faculty involvement in spin-offs & 4 \\
\hline & 02b Organizational relationship & 9 \\
\hline & 02c Research cooperation & 12 \\
\hline & 02d Communication outside the research (and marketing) & 6 \\
\hline & 02e Cooperation in other areas & 8 \\
\hline & $\begin{array}{l}02 f \text { Characterization of contacts between parent } \\
\text { organization and firm }\end{array}$ & 12 \\
\hline \multirow[t]{4}{*}{ Cognitive benefits } & 03a Knowledge advantages of access to data & 6 \\
\hline & 03b Knowledge benefits of businessacumens & 11 \\
\hline & 03c Knowledge benefits of the research agenda & 8 \\
\hline & 03d Knowledge benefits reflection and motivation & 7 \\
\hline \multirow[t]{7}{*}{ Conditions } & 07a Comparable time assessment & 11 \\
\hline & 07b Working within a similar subject domain & 11 \\
\hline & 07c Character traits employees and trust & 12 \\
\hline & 07d Geographical proximity & 12 \\
\hline & 07e IP and open research culture & 12 \\
\hline & $07 f$ Other factors affecting the interaction & 4 \\
\hline & 07g People exchange & 4 \\
\hline
\end{tabular}

\section{Analysis}

Resolute Actions by Individuals

From the interviews and data collected, respondents accentuated the importance of incorporating knowledge, skills, and associated assessments into the university program and is consistent with the literature (Ravi \& Janodia, 2021). Table 3 offers a divergence between conventional and changing perceptions on AE. The traditional justification for $A E$ is to augment the exploitation of the university's R\&D and create a direct return on investments (ROI) for the university. The finding on $A E$ reveals that universities already have robust technologymarket matching activities, such as start-ups,
USOs, patents, licenses, and TTOs. This entails going beyond direct knowledge and technology transfer and can ultimately result in creative human intervention in pursuing value-added economic activities such as developing innovative products, processes, or markets. (Wagner et al., 2021).

Concerning RQ1, university spin-offs are essential tools for creating and capturing value from scientific inventions. Fundamentally, an academic spin-off happens when the academic entrepreneurs acquire business know-how or develop a new technology that will, in the future, be used to fund the university's business incubator to create a product or a business 
concept that will be commercially viable. Individual who plays a vital role in the USO comprises the researchers or inventors, the academic or surrogate entrepreneurs, the entrepreneurial team, and privileged witnesses.

Table 3: Conventional vsChangingPerceptions on $\mathrm{AE}$

\begin{tabular}{|c|c|c|}
\hline Thematic Statements & Conventional Perceptions & Changing Perceptions \\
\hline $\begin{array}{l}\text { Strategies adopted by universities } \\
\text { for academic entrepreneurship }\end{array}$ & To create direct ROI & $\begin{array}{l}\text { To create an extensive societal and } \\
\text { financial value to the university } \\
\text { ecological community }\end{array}$ \\
\hline $\begin{array}{l}\text { Revamping programs to accom- } \\
\text { modate new AE models }\end{array}$ & $\begin{array}{l}\text { USOs, patents, licenses, } \\
\text { and TTOs }\end{array}$ & $\begin{array}{l}\text { Postdocs and graduates start-ups; } \\
\text { Ambitious and enterprising students; } \\
\text { building job bank in the community }\end{array}$ \\
\hline $\begin{array}{l}\text { Forming entrepreneurial groups } \\
\text { after the incubation stage }\end{array}$ & $\begin{array}{l}\text { Academe and postgraduate } \\
\text { students }\end{array}$ & $\begin{array}{l}\text { Students; Alumni; on-campus } \\
\text { business partnerships; surrogate } \\
\text { entrepreneurs }\end{array}$ \\
\hline $\begin{array}{l}\text { Establish 'multi-dextrous' (i.e., } \\
\text { social \& commercial start-ups, } \\
\text { licensing, etc.) academic } \\
\text { entrepreneurship activities in } \\
\text { university }\end{array}$ & $\begin{array}{l}\text { Tech transfers; industrial } \\
\text { parks }\end{array}$ & $\begin{array}{l}\text { Super fans; Entrepreneurship pit-stops; } \\
\text { student business plan competitions; } \\
\text { social media; business networking with } \\
\text { industry and alumni; worker mobility; } \\
\text { private start-ups and corporate spins-off }\end{array}$ \\
\hline
\end{tabular}

According to Shah \& Pahnke (2014), there is a significant change apart from spin-offs and intellectual property rights, an expanded variety of USOs, particularly the strong interest in graduate start-ups. These start-ups usually require less financing; however, they need specific assistance from TTO to enable them to succeed. The term spin-off refers to both the outcome and the process that produces that outcome. It implies that the new entity, its entrepreneurs, the technology used in the new venture, or all three, allowed to leave by a pre-existing organization, otherwise known as the mother organization. The outcome of this process is a new business spin-off.

In the focus group meetings, it is unsurprising that their core actions change as the projects evolved. At the outset, both Group 1 and 2 members considered themselves to be faculty staff than entrepreneurs, nevertheless gravitating progressively towards their entrepreneurial role. Group 1 devoted its time to developing a relationship with the community and expanding the business idea. When the business idea became apparent, the group turned their attention to commercially viable research, where they have competency in the domain. Over at Group 2, they intended to secure internal funding first within the university and gradually obtain outside financing. Entrepreneurs seem to gain knowledge first then transit to USO actualization. Without a doubt, the collaboration with industry and potential consumers was vital in expanding the members' skills, connections, and familiarity levels. However, Group 1 professors chance upon a possible business opening but were slow to bring it to fruition.

The belief of Group 2 was to collaborate with an industrial company, similarly with Group 3, as a result of consultations amongst researchers and industry partners. On the contrary, Group 4's experience with end customers in industrial applications was a critical success factor. They can realize business openings through technology-market matching. This validates the value of user experience (Mlekus et al., 2020).

\section{The Evolution from University to Corporate Settings}

The focus group discussions provide detailed accounts of the reasons the main actors influenced the spin-off process. Initially, different actors played distinct functions and responsibilities at various stages of the incubating process. For example, in Group 4, one university lecturer, together with his business associate, developed the technology but 
could not bring it to fruition in the marketplace. But with the facilitation of an astute entrepreneur was the project successful.

In Group 1, where they do not have the expertise, they purposefully engaged specialists in the start-up team vis an intrapreneur and an attorney. Over at Group 3, the professors collaborated with industry players and the university technology transfer office (TTO) until they could identify a suitable industrialist to hasten the project.

Table 4: Symbiotic relationships between the Universities and the Spin-off Projects

\begin{tabular}{|c|c|c|c|c|}
\hline University Role & Group 1 & Group 2 & Group 3 & Group 4 \\
\hline $\begin{array}{l}\text { Usage of university } \\
\text { R\&D facilities }\end{array}$ & None & Substantial & Substantial & $\begin{array}{l}\text { Informal minimal } \\
\text { use }\end{array}$ \\
\hline $\begin{array}{l}\text { Usage of basic } \\
\text { administrative facilities }\end{array}$ & $\begin{array}{l}\text { Start-ups } \\
\text { within university }\end{array}$ & $\begin{array}{l}\text { Industrial park incu- } \\
\text { bator near campus }\end{array}$ & $\begin{array}{l}\text { Start-ups within } \\
\text { university }\end{array}$ & None \\
\hline $\begin{array}{l}\text { Usage of university } \\
\text { business consulting }\end{array}$ & None & $\begin{array}{l}\text { University management } \\
\text { and industrial park }\end{array}$ & TTO & Industrial Park \\
\hline $\begin{array}{l}\text { Participation in } \\
\text { university TTO }\end{array}$ & Direct informal & Yes & $\begin{array}{l}\text { Involvement of } \\
\text { TTO and partial } \\
\text { IP rights owner }\end{array}$ & None \\
\hline $\begin{array}{l}\text { Usage of university } \\
\text { resources to boost } \\
\text { spin-off project }\end{array}$ & $\begin{array}{l}4 \text { faculty staff on } \\
\text { sabbatical year }\end{array}$ & $\begin{array}{l}\text { University funding to } \\
\text { obtain patents }\end{array}$ & $\begin{array}{l}\text { University is } \\
\text { technology } \\
\text { partner offering } \\
\text { research }\end{array}$ & None \\
\hline Faculty involvement & None & $\begin{array}{l}\text { Appointed by Group } 2 \\
\text { to undertake } \\
\text { experimentations }\end{array}$ & $\begin{array}{l}\text { Yes faculty involve } \\
\text {-ment in R\&D } \\
\text { project }\end{array}$ & $\begin{array}{l}\text { Negligible } \\
\text { participation at } \\
\text { university }\end{array}$ \\
\hline Learner involvement & $\begin{array}{l}\text { Recruiting base } \\
\text { and dissertation } \\
\text { undertaking }\end{array}$ & $\begin{array}{l}\text { Recruiting base and } \\
\text { dissertation undertaking }\end{array}$ & $\begin{array}{l}\text { Recruiting base } \\
\text { and dissertation } \\
\text { undertaking }\end{array}$ & $\begin{array}{l}\text { Dissertation } \\
\text { projects }\end{array}$ \\
\hline
\end{tabular}

The four focus groups in this study differed in their dealings with their institutions. Group 2 and 3 had better relationships with the university, such as control, TTO usage, and joint research. Group 1 and particularly Group 4 was less cohesive with the university. Nevertheless, all groups had symbiotics relationships with the university, as summarized in Table 4.

The university ecosystem was deemed munificent by the spin-off entrepreneurs, primarily of the university's involvement in the financial risk associated with seeding a business concept such as free time, paraphernalia, consultancy service, and start-up services. Prospects of professors at Group 1 taking sabbaticals made it possible to be engaged in the business spin-off with no necessity of leaving their current job. In Group 2, the university aggressively exploited people's networks to gain connection to professional expertise. As the spinoffs evolve, the institution subsequently became a collaborator.

Concerning RQ2, the spin-offs are not without their woes: Some actors within the university worry that spin-off activity would erode their research work, 
thereby triggering an uncomfortable partnership between them of mixing academic research with commercialization activities. Sometimes because of contentious discussions, clashes become apparent with TTOs, then efforts are needed to address the plight. While faculty members' involvement in research commercialization activities stimulates $A E$, a befitting stimulus facilitates the commercialization process.

Again, the members in Groups 1 and 4 decided that there should be a clarity of their roles/responsibilities as they view their work as transitory from academe to the world of work.

In relationship with the university keeping the inherent disputes of intellectual property ownership, Group 1 conducted their developmental efforts entirely within the team with no involvement of university staff nor its R\&D facility.

External collaboration with partners outside the university is vital for faculty members to have the opportunity to spot and adapt a potential business idea to fruition. It is in the interest of researchers to build up a positive reputation and credibility with the industry through engaging with financiers who provide the necessary start-up capital. The challenge for faculty members is to resolve the disparities in aspiration, pursuits, objectives, and expectations with the industry actors.

\section{Transient Events and Environmental Changes}

The evolution from university to corporate settings discussed above, several transient events and environmental changes have significant direct influences on the spin-off processes (Vega-Gómez et al., 2020). The connection between universities and business incubators (BIs) is essential as universities deliver knowledge, conduct research, and drive invention. Therefore, having a BI program within the university embodies a strategic advantage for academe, as universities can contribute important linkages to the industry, private and public sectors.

Concerning RQ3, external factors influenced the business incubating processes, such as access to capital, legislative policies, employment market situations, and regional business environment. In the case of Group 4, they were unable to commit considerable funding in advanced technology. There is no assurance of success in venturing until a researcher at another university identified it as an opportune time for a start-up. Another instance of changing business landscape was apparent in Group 2. A steep recession in the business affiliate's share price triggered their exit from the R\&D plan, rendering the USO formation the only option.

The reciprocal arrangement of industry and Group 2 came to a standstill as their disagreements on the project handling between members of the group and the $\mathrm{BI}$ leader became untenable. In Group 1, the project was halted because of individual differences and opinions as to how the project should be managed. These cases illustrate transient events can and will affect the successful project spin-offs. The different ideas on innovation, participation, and group risk behaviors can be critical for USOs. In sum, the information exchange is likely to be contingent on a variety of cultural determinants of $A E$.

\section{Reimagining Academic Entrepreneurship}

Given that universities are notoriously diverse, from the perspective of the resource endowments and stages of development, it may be unsuitable for universities that are not research-based to pursue AE activities such as USOs. But instead to engage individuals in galvanizing the right entrepreneurial spirit and attitude through appropriate channels in university or social discourse.

As universities forge ahead in developing policies for expanding the scope of $A E$, there were a few concerns expressed. There must be realistic KPls (key performance indicators) established in monitoring the success of AE activities, for example, the efficacy of universities and TTOs regarding patent licensing and commercialization procedures. The unfolding of AE has shown that such activities present practical challenges to universities, as university managers have their agenda not necessarily aligned to the university's goals.

One untapped aspect of personal participation in AE relates to the responsibility of global alliances among academics. Vasojević \& Kirin (2019) has underscored the importance of returning academics and preserving global partnerships unavailable to $A E$. Accordingly, literature on entrepreneurial 
mobility reveals that returning entrepreneurs can generate a considerable spillage influence that fosters innovation in the home country of the returnee (Li et al., 2018). Consequently, the TTOs provided a haven for entrepreneurial talents and business collaborations in faculty and graduate startups. Traditionally TTOs focus on obtaining patents and licenses but place less emphasis on transferring technology and social entrepreneurship.

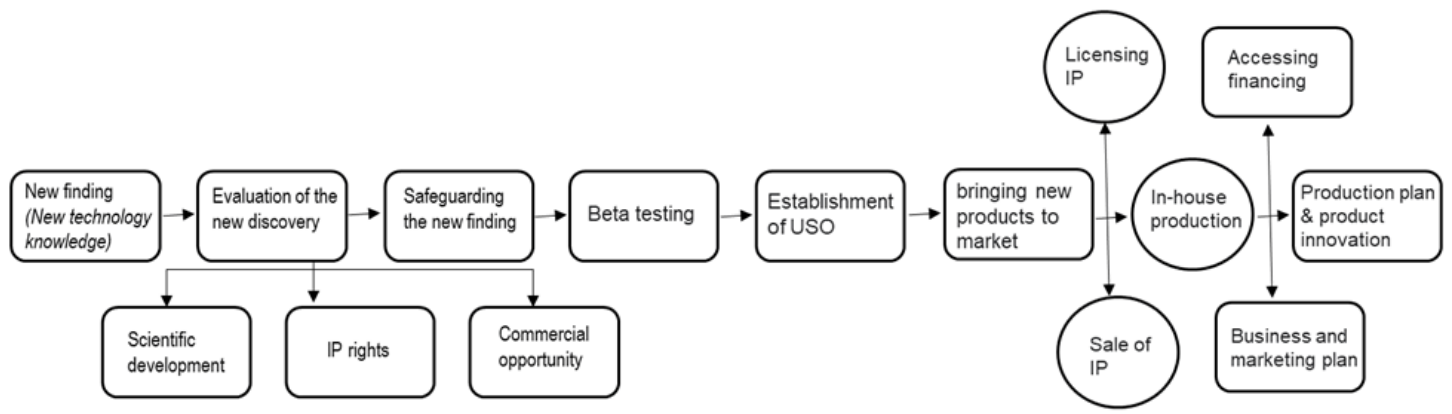

Fig.1: Stage-Gate Models of USO (author's adaptation)

With the above-discussed AE from conceptualization (discovery) to commercialization of USO, it may be observed that these works are stage-based models. The entire journey (experiences) of the four focus groups is encapsulated in the following Figure 1.

\section{Findings}

The results suggest that universities have important recommendations to become more entrepreneurial and innovative and in the direction of what Bezanilla et al. (2020) called entrepreneurial universities. It requires a purposeful review of the university's assistance for individuals' intentions to cultivate a USO or new business start-ups based on selfefficacy. In its essence, self-efficacy refers to individuals' sense of convictions and capacity to take effective action and not strictly based on entrepreneurial skills. Because entrepreneurial attitude and spirit are likely to affect positively, members of the university community can facilitate and support researchers in their endeavors.

It is essential to imbuing principal stakeholders, for example, TTO and research faculty, by connecting the researcher's innate ability with commercial applications. Unsurprisingly, many researchers are not enthusiastic about the commercial applications of their novelties. They instead go back to their research work and journals. This gulf implies that as the AE paradigm continues to evolve, the greater impetus must be placed on how academe can be motivated and compensated for their discovery beyond the KPIs for scholarly publications.

Based on the finding, the author infers that novelty and consummation is an integral component of becoming an entrepreneurial university. The university is invited to redraw its policies on business incubators as an institutional form of $\mathrm{AE}$. Moreover, the collaboration and partnership between the university and the business community need to be recalibrated for long-term profitability and sustainability, forcing a paradigm shift of the academic community and the relevant organs of the university. They are invariably causing the transfer of knowledge from academe to practice being much more efficient when empowered by the university's top management.

Concerning the key success considerations that positively influence the effective collaboration between academe and businesses, which the respondents cite in the study, are the real-world application of academic knowledge for the scientific advances, good incentive schemes, community networking, and open communications.

This study contributes towards the third mission of universities by addressing the community's experience and skills requirements. A unique way of achieving this is through fostering collaboration between university-industry-government; and raising public awareness in local communities to reduce social exclusion and improve cultural understanding. 


\section{Discussion \\ Reconstruction of Toolkit for AE}

The results from the in-depth interviews and a series of workshopsshow that the AE toolkit is built on four mutually dependent themes:

\section{The Structure of an Enterprising University and its Culture}

The majority of the respondents cited the symbiotic relationship of $A E$ and the transformation of the university and its culture. This pushes the frontier of the university's traditional role as an institution of higher learning into augmenting $\mathrm{AE}$ within the sustainable relationship with the community.

This theme acknowledges the critical activities of the universities, most notably the third mission visà-vis the enduring association of higher education and research pursuits with cultivating USO or new business start-ups. The universities are to champion the prioritization of institutional policies, such as promoting societal programs that enhance all agents' active participation in the entrepreneurial and innovation ecosystem (Fischer et al., 2020). In analyzing the delivery of higher education and the opportunity of technology-market matching to businesses, it leads us to reflect on the larger purpose of education - that we are not spectators but intrinsically connected in the process. The vehicle for bridging this divide offers practical support and activities, such as establishing science parks, USO, patenting and licensing, etc.

\section{University Spin-offs and Applied Research}

The central tenet in this theme is the academic spin-offs. The mother organizations refer to the universities which play an essential role as creators of technological results. Essentially the specialized products are developed by the academe with the intent of commercialization for profitability. It is crucial to have diverse knowledge and pertinent resources in enabling USO, such as access to the university's R\&D or TTO. The university's other helpful roles are direct funding assistance, professional counsels, and an office area for nascent ventures, including networking opportunities with university connections.

According to Mathisen \& Rasmussen (2019), emerging innovations from the USO perspective arises iteratively and randomly. Further, the expertise of high-tech sectors, where most USOs are operating, is usually in its infancy phase, evolving and complex. Hence, the steps necessary in turning academic knowledge/technologies into a viable product/service necessitate skills and competencies that are lacking across universities and academic entrepreneurs. Furthermore, several TTOs do not have the funds, including tenacities, to spin off the commercialization of education technologies and ideas.

\section{The Attribute of Academic Entrepreneurs and Entrepreneurial Ecosystem}

The most critical component for the USO process is the entrepreneur. The USO entrepreneurs refer to academic teaching staff who are professors, researchers, or postdocs. The reality of them exiting the university for business start-ups is mixed depending on whether they are incentivized or appropriately compensated. However, it is conceivable for a USO to be founded by a surrogate entrepreneur. This surrogate entrepreneur refers to an external entrepreneur to the university, but it is the university that transfers the technology to this new venture.

The academic entrepreneurs' capacity to find potential start-up opportunities can be ascribed to varied business skill sets and competencies. Although the research experience of academic entrepreneurs may trigger new business ventures, the collaborative efforts between academe and industry partners would invigorate technological opportunities. It is noteworthy that academic entrepreneurs have a predisposition to developing new products only if the universities provide necessary enterprise connections and spur such behaviors as business incubators and science parks.

\section{Spin Off Development and Community Engagements}

Considering $A E$ evolution, different universities must define entrepreneurial processes relevant to entrepreneurs and the institutions so that the financial stream can be actualized. Additionally, it addresses $A E$ from an ecosystem consisting of researchers, teams, and institutional culture. Especially the role of universities has now moved from conventional to entrepreneurial models, whereby creating new knowledge for economic development through business incubators (Hausberg \& Korreck, 2020). To facilitate the conversion of ideas into business 
reality, universities must incorporate an ecosystem that can bring together knowledge to promote frugal innovation (Melkas et al., 2019). Eventually, this signifies a change from the conventional view of spinoffs and academe, turning frugal innovations into a "harvesting" paradigm conceived in transparent innovation strategies (Ardito et al., 2018).

There is a widespread belief that universities nowadays have unique expertise and greater accountability in facilitating scientific knowledge transformed into feasible commercialization. The community's ever-changing needs call for the intimate association between universities and industry to tackle the headwinds facing society; undeniably, this is the precursor of the prosperity of nations.

\section{Implications for Further Research}

In using the toolkit, this study reveals various facets of USO developments. It proposes opportunities for future research on bridging $A E$ and the world of work through technology-market matching. However, the theories are relatively broad, which makes them applicable to research on spin-off venture development. Further research might also examine mature spin-offs, as well as in the spin-off firms that do not collaborate with research institutions or have a disagreement with their parent organization.

From a practical perspective, further suggestions can be drawn from assessing both the parent research institutions and the spin-off firms by keeping effective and constructive relationships. Unpredictable circumstances and changing environments may be challenging to anticipate. Hence it is helpful for parent organizations to maintain a close relationship because there are mutual benefits and collective research interests. Since technologybased academic entrepreneurship invites research attention, they are the desired partner in contrast to many other companies. At its heart, the challenge essentially involves both partners investing in regular communications and staff exchange to transfer knowledge.

Next, suppose universities desire to upsurge the USO's influence and social capital. In that case, they must consider developing or expanding social and business networking, recruiting individuals with good business connections to help emerging entrepreneurs, and TTO to extend comprehensive services to spur social capital.

\section{Implications for Practice}

The toolkit opens up several implications for practice. For example, universities need to have an acute knowledge of each process stage to facilitate or smoothen the spin-off development. Faculty members will be expected to understand how the university stipulates conflicts of commitment or tension over faculty responsibilities; transition from research endeavor to commercial enterprise.

The resolute actions by individuals suggest the significance of committed and competent individuals to the spin-off process. This individual can be made accessible to the ventures both across the sandbox learning and staff exchanges. Individuals' motives, motivations, and abilities/experiences are imperative to securing dedicated and proficient individuals through training curricula and community events. Unfortunately, the universal axiom "one-size-fitsall" strategy (in spin-offs) should be circumvented. Fledging academic entrepreneurs must ask pertinent questions that can best provide or support their ambition, for example:

- Is this a viable business and sustainable?

- Does the collaborative partner have the means/ expertise and support of my business?

- Do they understand what the best marketing penetration method for my business is?

- $\quad$ Are there any track records of past successful ventures?

Academic entrepreneurs need to be conscious of the risks associated with the conversion from academia to corporate. From the university policymaker's perspective, all the policies and operating procedures within the faculty should enable the AE process and bring to fruition the technology-market matching. The overarching tenacity of the university in the technology-market matching seems to be even more significant than any other university policies.

\section{Limitations of the Research}

The study does not come without its limitations. It is envisioned that future research will pursue unpacking the impacts of this organizational change. On the one hand, the supply-side (i.e., traits and mindsets of individuals) and the other demand- 
side (i.e., detailed environment, e.g., the societal culture of the university) aspects that motivate engagement in $\mathrm{AE}$ and technology-market matching. The relationship between academe first mission and $A E$, and the responsibility of other actors such as graduate students, alumni, including external researchers in the private sectors will be investigated (Marzocchi et al., 2019).

The researchers endeavored to apply an unbiased assessment when combing through the vast amount of existing literature on the topic at hand. The intention was to report on the vital role of academics transiting from university to industry, given the unique business context in developing nations such as Malaysia and Cambodia. This study sought to distinguish important enactment issues a newly sponsoring university could learn from as it recalibrates actions towards expanding a third mission based on technology transfer and research commercialization activities. Learning from other institutions from advanced economies should help policymaking of the university, and procedure development, while enabling the quest of the university's third mission to achieve institutional and national objectives.

\section{Concluding Remarks}

The survey results expose the tradition of universities and the technological transfer in developing economies. In order to render technology transfermore pertinent, the followings are suggested:

- $\quad$ To facilitate USOs, the author proposes setting up a national institute for entrepreneurship and small business development to align its key initiatives. Further, introducing a tactical promotion that will spur interest in $\mathrm{AE}$ and a holistic review of entrepreneurial studies is part of the more extensive curriculum in the university teaching framework.

- To be effective and add value to entrepreneurs, TTO must include specialized personnel in the specific domain to provide more resources to them like drafting marketing plans and specific USO strategies. Generally, university's support for the USO is limited to advice on how to incorporate a new company and the professional guidance on strategic competitive advantage.

- To advocate long term sustainability and profitability, university must create a strong, dependable and active alumni and business network to support the entrepreneurs.

- To introduce financial support and legal assistance to entrepreneurs and matchmake them with the keen interest of private sectors.

- To augment term of reference (TOR) for the USO and facilitate the incubation process leading to enhancement and ultimately profitability and sustainability.

- $\quad$ Finally, skilled and competent actors are the pillar of all institutions and particularly incubators. In the business arena, the sustainable competitive advantage comes from its highly qualified individual working in communities.Currently, in many university TTOs, the responsibility falls on faculty/staff who does not have the necessary business experience, expertise, and skills. This results in a halo effect and the desired results are frustrating. Proactive universities can encourage interdisciplinary research and harness domain strengths.

\section{Acknowledgment}

This research received no specific grant from any funding agency in the public, commercial, or notfor-profit sectors.

\section{Funding}

The author(s) received no financial support for the research, authorship, and/or publication of this article.

\section{Conflict of Interest}

The author declares there is no conflict of interest.

\section{Reference}

1. Ardito, L., Ferraris, A., Petruzzelli, A. M., Bresciani, S., and Giudice, M. del (2018). The role of universities in the knowledge management of smart city projects. Technological Forecasting and Social Change, 142, 312-321.

2. Audretsch, D. B. (2014). From the entrepreneurial 
university to the university for the entrepreneurial society. Journal of Technology Transfer, 39(3), 313-321.

3. Balven, R., Fenters, V., Siegel, D. S., \& Waldman, D. (2018). Academic entrepreneurship: The roles of identity, motivation, championing, education, work-life balance, and organizational justice. Academy of Management Perspectives, 32(1), 21-42.

4. Banerski, G., Gryzik A., Matusiak KB, Mażewska M., Stawasz E. (2009). Academic entrepreneurship (development of spin-off and spin-out companies) -training for its development. Research report, Poland, Agency for Enterprise Development, Warsaw.

5. Bezanilla, M. J., García-Olalla A., PañosCastro J. \& Arruti A. (2020). Developing the entrepreneurial university: Factors of influence. Sustainability (Switzerland), 12(3).

6. De Almeida Borges, P., De Araújo L., Lima L., Ghesti G., Souza Carmo T. (2020). The triple helix model and intellectual property: The case of the University of Brasilia. World Patent Information, 60.

7. De Boer, Harry, \& Jürgen Enders (2017). Working in the Shadow of Hierarchy: Organisational Autonomy and Venues of External Influence in European Universities. Ivar Bleiklie, Jürgen Enders, and Benedetto Lepori (Eds.), Managing Universities, 57-83. Cham: Springer International Publishing

8. De Silva, M. (2016).Academic Entrepreneurship and Traditional Academic Duties: Synergy or Rivalry? Studies in Higher Education. 41 (12), 2169-83.

9. Dost, M., Pahi, M., Magsi, H., \& Umrani, W. (2019). Effects of sources of knowledge on frugal innovation: moderating role of environmental turbulence. Journal of Knowledge Management, 23(7), 1245-1259.

10. Fischer, Bruno, Guerrero, Maribel, Guimón, José \& Schaeffer, Paola Rücker (2020) Knowledge transfer for frugal innovation: where do entrepreneurial universities stand? Journal of Knowledge Management, 25(2), 360-379.

11. Fleming, P. (2020). Dark Academia: Despair in the Neoliberal Business School. Journal of Management Studies, 57 (6), 1305-11.

12. Gubbins, M., Harrington, D. and Hines, P. (2020). Social support for academic entrepreneurship: definition and conceptual framework. Journal of Management Development, 39(5), 619-643.

13. Hausberg, J. \& Korreck, S. (2020). Business incubators and accelerators: a co-citation analysis-based, systematic literature review. Journal of Technology Transfer, 45(1), 151-176.

14. Hayter, C. S., A. J. Nelson, S. Zayed, and A. C. O'Connor. (2018).Conceptualizing AE Ecosystems: A Review, Analysis and Extension of the Literature. The Journal of Technology Transfer, 43 (4), 1039-82.

15. Hogan, O., M. A. Kortt, and M. B. Charles. (2021). Mission Impossible? Are Australian Business Schools Creating Public Value? International Journal of Public Administration 44 (4), 280-289.

16. Jack, A. (2020, February 24). Academic Focus Limits Business Schools' Contribution to Society.Financial Times. https:// www. ft.com/content/5953739c-3b94-11ea-b84fa62c46f39bc2.

17. Li, C.G., Isidor, R., Dau, L.A. \& Kabst, R. (2018). The more the merrier? Immigrant share and entrepreneurial activities. Entrepreneurship Theory and Practice, 42(5), 698-733.

18. Łukasz Siemieniuk (2015). Academic Business Incubators as an institutional form of academic entrepreneurship development in Poland, Institute of Economic Research Working Papers No. 97/2015.

19. Mars, M. M., and C. Rios-Aguilar. (2010). Academic Entrepreneurship (re) Defined: Significance and Implications for the Scholarship of Higher Education. Higher Education, 59 (4): 441-60.

20. Marzocchi, C., Kitagawa, F., \& SánchezBarrioluengo, M. (2019). Evolving missions and university entrepreneurship: academic spin-ofs and graduate start-ups in the entrepreneurial society. The Journal of Technology Transfer, 44(1), 167-188.

21. Mathisen, M. T., \& Rasmussen, E. (2019). The development, growth, and performance of university spin-offs: A critical review. The Journal of Technology Transfer, 44(6).

22. Melkas, H., Oikarinen, T., \& Pekkarinen, S. (2019). Understanding frugal innovation: a case study of university professionals in developed countries. Innovation and Development, 9(1), 25-40.

23. Mlekus, L., Bentler D., Paruzel A., KatoBeiderwieden A, L., Maier G. W. (2020). 
How to raise technology acceptance: user experience characteristics as technologyinherent determinants. Gruppe. Interaktion. Organisation. Zeitschrift fur Angewandte Organisations psychologie. 51(3).

24. Mohar, Y., Zulkiflee, A.S., Fadzil, H., Zuhairuse MD.D., Mohammad F.M., Azami, Z. (2010). Academic entrepreneurship and innovation in higher education: an integrated framework for Malaysian Universities. Advances Educational Technologies, http://www.wseas.us/e-library/ conferences/2010/Tunisia/EDUTE/EDUTE-04. pdf.

25. Mohr, L. B. (1982). Explaining Organizational Behavior. Jossey-Bass Publishers.

26. Mustar, P., Renault, M., Colombo, M.G., et al. (2006) Conceptualizing the heterogeneity of research-based spin-offs: A multidimensional taxonomy. Research Policy, 35(2), 289-308.

27. Nguyen, V.T., Nguyen, T. L. \& Nguyen, H.H. (2018). Fostering academic entrepreneurship: A qualitative study of invention commercialisation. Journal of Development Entrepreneurship, 23(4), 1-23.

28. Phan, P. H., \& D. S. Siegel. (2006). The Effectiveness of University Technology Transfer. Foundations and Trends in Entrepreneurship, 2 (2): 77-144.

29. Pilegaard, M., Moroz, P.W. and Neergaard, H. (2010). An Auto-Ethnographic Perspective on Academic Entrepreneurship: Implications for Research in the Social Sciences and Humanities. Academy of Management Perspectives, 24, 46-61.

30. Pisoni, A., Michelini, L., \& Martignoni, G. (2018). Frugal approach to innovation: State of the art and future perspectives. Journal of Cleaner Production, 171, 107-126.

31. Rao, B. (2019). The science underlying frugal innovations should not be frugal. Royal Society Open Science, 6(5),1-8.

32. Ravi, R., \& Janodia, M. (2021). Factors Affecting Technology Transfer and Commercialization of University Research in India: a Cross sectional Study. Journal of the Knowledge Economy, https://doi.org/10.1007/s13132-021-00747-4.

33. Scott, W. Richard, \& Michael W. Kirst (2017). Higher Education and Silicon Valley: Connected but Conflicted. Baltimore: Johns Hopkins University Press.

34. Shah, S. and Pahnke, E. (2014). Parting the ivory curtain: Understanding how universities support a diverse set of startups. Journal of Technology Transfer, 39(5), 780-792.

35. Siegel, Donald S., \& Mike Wright. (2015a). Academic entrepreneurship: Time for a rethink? British Journal of Management Studies 26(4), 582-595.

36. Siegel, Donald S., and Mike Wright. (2015b). University Technology Transfer Offices, Licensing, and Startups. In Albert N. Link, Donald S. Siegel, \& Mike Wright (Eds.), the Chicago Handbook of University Technology Transfer and Academic Entrepreneurship, (pp.1-40). The University of Chicago Press.

37. Steinfield, L., \& Holt, D. (2019). Toward a Theory on the Reproduction of Social Innovations in Subsistence Marketplaces. Journal of Product Innovation Management, 36, 764-799.

38. Tajpour, M., Hajian, F., \& Nabaei, A., (2017), The Impact of Suggestions to Entrepreneurial opportunity recognition Case study: Bank Tejart of Iran, International Journal of Management Sciences and Business Research, 12-45-53.

39. Tajpour, M., Kawamorita, H., \& Demiryurek, K.(2020). Towards the third Generation of Universities with an Entrepreneurial Approach, International Journal of Technoentrepreneurship, 4(2),122_134, https://doi.org/10.1504/ IJTE.2020.113927

40. Tajpour, M. \& Hosseini,E. (2019). Designing a pattern of University Social Responsibility in Higher Education Development with Emphasis on Corporate Entrepreneurship. Paper presented at the Conference: Ethics-oriented University Conference at: Tehran, University of Tehran, Tehran.

41. Van de Ven, A.H.\& Poole, M.S. (1995). Explaining development and change in organizations. Academy of Management Review, 20(3), 510-540.

42. Van Nguyen T., Tuong Nguyen L., \& Ba Nguyen N. (2018). Fostering Entrepreneurship among Academia: A Study of Vietnamese Scientist Commercialization. Journal of Economics and Development, 20(3), 88-102.

43. Van Toan D. (2021). Research on the Model of Entrepreneurial University and Advanced University Governance: Policy Recommendations for Public Universities in Vietnam. VNU Journal of Science: Policy and Management Studies, 37(1). 
TEO, Journal of Business Strategy, Finance and Management, Vol. 02(1 \& 2) 115-130 (2021) 130

44. Vasojević, N. A. \& Kirin, S. (2019). Life satisfaction of returnee scholarship holders in Serbia, Stanovnistvo. 57(2).

45. Vega-Gómez, F. I., Miranda González, F. J., and Pérez-Mayo, J. (2020). Analyzing the Effects of Institutional- and Ecosystem-Level Variables on University Spin-Off Performance. SAGE Open. 10(2).

46. Wadhwani, R. D., G. Galvez-Behar, J. Mercelis, and A. Guagnini (2017).AE and Institutional Change in Historical Perspective. Management \& Organizational History,12 (3): 175-98.

47. Wagner, M., Schaltegger, S., Hansen, E., \& Fichter, K.(2021). University-linked programmes for sustainable entrepreneurship and regional development: how and with what impact? Small Business Economics, 56(3), 1141-1158.

48. Wright, M., Clarysse, B., Lockett, A., and
Knockaert, M. (2008). Mid-range universities' linkages with industry: Knowledge types and the role of intermediaries. Research Policy, 37(8), 1205-1223.

49. Yin, R. K. (2003), Case Study Research: Design and Methods, Sage, Thousand Oaks.

50. Zhylinska, O., Sitnicki, M., \& Vikulova, A.(2019). Systematic assessment of the innovative potential of a research university. Baltic Journal of Economic Studies, 5(2).

51. Ziyae, B., \& Tajpour, M. (2016). Designing a comprehensive model of entrepreneurial university in the science and technology parks. World Journal of Entrepreneurship, Management and Sustainable Development, 12(3), 267-280. i https://doi.org/10.1108/ WJEMSD-04-2016-0022 